\title{
Freshwater mollusks from three reservoirs of Piauí, northeastern Brazil
}

\author{
Edson Lourenço da Silva ${ }^{1}{ }^{\mathbb{D}}$, Adriana Josefa da Rocha ${ }^{2}$, Manuella Feitosa Leal ${ }^{3}$, Orianna dos Santos ${ }^{2}$, João \\ Hemerson de Sousa², Antônia Rafaela Viana da Silva', Karina Ketelen Silva Dantas ${ }^{2}$, Erika Maria Matos \\ Rulim $^{2}$, Emerson Santos Castro ${ }^{2}$, Ana Carolina Landim Pacheco ${ }^{2}$ \& Tamaris Gimenez Pinheiro ${ }^{2 *}$ (D) \\ ${ }^{1}$ Instituto Federal do Piaui, Picos, PI, Brasil \\ ${ }^{2}$ Universidade Federal do Piauí, Picos, PI, Brasil \\ ${ }^{3}$ Universidade Federal da Paraíba, Programa de Pós-Graduação em Ciências Biológicas-Zoologia, \\ João Pessoa, PB, Brasil \\ *Corresponding author: Tamaris Gimenez Pinheiro,e-mail: tamarisgimenez@yahoo.com.br
}

SILVA, E. L, ROCHA, A. J., LEAL, M. F., SANTOS, O., SOUSA, J. H., SILVA, A. R. V., DANTAS, K. K. S., RULIM, E. M. M., CASTRO. E. S., PACHECO, A. C. L., PINHEIRO, T. G. Freshwater mollusks from three reservoirs of Piauí, northeastern Brazil. Biota Neotropica. 20(1): e20190868. http://dx.doi.org/10.1590/16760611-BN-2019-0868

\begin{abstract}
The pronounced dry season determines the characteristics of the semiarid region of Brazil. Numerous small reservoirs are built to overcome this condition, accumulating multiple uses and causing important changes in the landscape and the local biota. Considering the limited amount of information about the malacofauna of reservoirs, mainly in the Northeast region of the country, this inventory provides a list of mollusks from three important reservoirs located in the city of São Julião, state of Piauí. The collections were carried out monthly between May/2017 and April/2018, sampling a total of 11,149 mollusks, corresponding to the species Melanoides tuberculata (Müller, 1774) ( $\mathrm{n}=9,724)$, Biomphalaria straminea (Dunker, 1848) $(\mathrm{n}=1,361)$ and Pomacea lineata (Spix, 1827) $(\mathrm{n}=64)$. The richness of mollusks from the three reservoirs was low, similar to those described in studies conducted in other regions of Northeast Brazil. There was a significant difference in the abundance of $M$. tuberculata and $B$. straminea among the studied reservoirs. These environments are not connected and are installed in urban and rural areas, presenting different ecological conditions. The relationship between the human population and the reservoirs, associated with the lack of sanitation, increases the risks of spreading waterborne diseases besides the development of environmental imbalance by the introduction of exotic species.
\end{abstract}

Keywords: Ampullariidae, Gastropoda, Planorbidae, species list, Thiaridae.

\section{Moluscos límnicos de três reservatórios do Piauí, nordeste do Brasil}

Resumo: O período de seca pronunciado marca a região semiárida brasileira. Para superação dessa condição inúmeros reservatórios de pequeno porte são construídos, acumulando múltiplos usos e causando alterações importantes na paisagem e na biota local. Considerando as poucas informações sobre a malacofauna de reservatórios, principalmente na região nordeste do país, este trabalho apresenta o inventário das espécies de moluscos provenientes de três importantes reservatórios localizados no município de São Julião, estado do Piauí. As coletas foram realizadas mensalmente entre os meses de maio/2017 e abril/2018. Foi amostrado um total de 11.149 moluscos, correspondentes as espécies Melanoides tuberculata (Müller, 1774) $(\mathrm{n}=9,724)$, Biomphalaria straminea (Dunker, 1848) $(\mathrm{n}=1,361)$ e Pomacea lineata (Spix, 1827) $(\mathrm{n}=64)$. A riqueza de moluscos amostrados nos três reservatórios foi baixa, não diferindo daquelas descritas em estudos realizados em outras regiões do Nordeste do Brasil. Houve diferença significativa na abundância de $M$. tuberculata e $B$. straminea entre os reservatórios estudados os quais não são conectados e encontram-se instalados em áreas urbana e rurais, com condições ambientais distintas. A relação entre a população humana da região e os reservatórios, juntamente com a falta de saneamento representam riscos à propagação de doenças transmitidas pela água e desequilíbrio ambiental pela introdução de espécies exóticas.

Palavras-chave: Ampullariidae, Gastropoda, lista de espécies, Planorbidae, Thiaridae. 


\section{Introduction}

The semiarid region covers a large part of the Northeast and a portion of the Brazilian Southeast (SUDENE 2017). This area is subject to recurrent and severe droughts periods (Ab'Sáber 2003) with spatial rainfall and temporal irregularity, providing edaphic high evapotranspiration and causing a serious water scarcity condition (Agostinho et al. 2007; Malvezzi 2007). Tundisi (2003) considers this scenario the main threat to the Brazilian Northeastern region biodiversity, driving to changes in natural environments dynamics and also in all communities that depend or live in freshwater.

Due to this ecological feature, a set of measures have been taken to reduce the impact of droughts in the Northeast and building dams has been an effective way to store water (Esteves 1998). Despite its intrinsic importance for the human population, the building of a reservoir severely changes local hydrology, moving streams from a lotic state to a lentic or semi-lentic condition (Agostinho et al. 2007, Tundisi et al. 2002). These changes produce considerable alterations in aquatic ecosystems, primarily due to variations in water residence time, habitat fragmentation and exotic species invasion (Tundisi 2008, Agostinho et al. 2005). These circumstances eventually promote the restructuring of the entire biota composition (Baxter 1977), allowing to species substitution and an increase on the abundance of more adapted species to the conditions of the new environment in opposition to the decrease of non-adapted ones.

Mollusca is an extraordinarily varied phylum, with estimates of $80,000-100,000$ described species and the total diversity possibly as high as 200,000 , they are behind only to arthropods in species richness (Strong et al. 2008). The mollusks have been successful in occupying most of all diverse freshwater habitats (Bogan 2008) with reports of phylogenetically distinct lineages and assemblages, of which Bivalvia and Gastropoda are cited as the most important classes (Lydeard et al. 2004). These animals participate in several ecological interactions within the community acting as filtering agents, herbivores, predators, ectoparasites, and commensal (Colley et al. 2012; Pombo 2016), besides carrying parasites intermediate forms.

Routinely and inadvertently, freshwater mollusks are introduced in new environments with aquatic plants, fish and anthropic action linked with aquaculture (Strong et al. 2008). Negative consequences of this introduction are diverse, including: (1) partial or total natural populations substitution (Freitas et al. 1987, Pointier 1999, Fernandez 2001); (2) health damage to both humans and other animals through the dissemination of larval stages of parasites (Pinto \& Melo 2011); and (3) economic, causing damages to companies building structures because of the accumulation of these organisms (Santos et al. 2012, Vogler 2012).

There is no systematized information about native mollusk fauna nor exotic regarding Brazilian reservoirs, and the few existing reports about this group are restricted to large dams, mainly those related to hydroelectric plants (Thiengo et al. 2005, Fernandez et al. 2018, Rocha et al. 2011, Fernandez et al. 2014). Likewise, studies focused on mollusk fauna of small and medium-sized reservoirs in the Brazilian Northeast built for water storage are still scarce (e.g., Santos \& EskinaziSant'anna 2010, Almeida et al. 2018, Medeiros et al. 2018). Considering the importance of the malacofauna previously described and the fact that small reservoirs accumulate diverse uses by the populations, the knowledge of its composition is extremely important. Thus, this work presents a list of mollusks species derived from three important reservoirs located in the northeastern of Piaui state, semiarid region.

\section{Material and Methods}

\section{Study area}

This research is part of the long-term survey project about the malacofauna from Guaribas Valley territory. This territory comprises an area of $22,822 \mathrm{~km}^{2}$ of Piauí state, reaching 23 cities (SEPLAN 2017). The studied reservoirs are in São Julião, a small city with 5,675 inhabitants, in the southeast of the state (IBGE 2019).

The sampling expedition occurred at São Julião reservoir, located in the urban area, Dona Maria Zeneide Viana de Andrade (former Piaus) and Emparedade reservoirs, both located in the rural area (Figure 1). Those survey points were chosen because they are perennial with massive presence of mollusks and accessible to the local human population.

\section{Sampling and data analysis}

Samplings were held monthly between May 2017 and April 2018 in three stations located 1.5 meters from the margin in each reservoir. The field procedures were done according to Silva et al. (2019). Sorting and identification of individuals were carried out at the Laboratory of Ecology, Parasitology and Neglected Diseases (LAPEDONE), at the Instituto Federal do Piauí.

The verification of normality in the data distribution occurred by applying the Shapiro-Wilk test. After not presenting normal distribution, there was the application of the Kruskal-Wallis nonparametric test to verify the differences in the abundance of mollusks between the reservoirs studied. The Kolmogorov-Smirnov test occurred a posteriori. All analyses used the SYSTAT ${ }^{\circledR}$ software, version 12.0.

The entire field procedure was authorized by Chico Mendes Institute for Biodiversity Conservation, through Biodiversity Authorization and Information System (SISBIO) permit number 60423-5. Voucher specimens are housed at Coleção de Moluscos do Instituto Oswaldo Cruz, Fundação Oswaldo Cruz, Rio de Janeiro, Brazil (CMIOC), Museu de Zoologia da Universidade de São Paulo, São Paulo, Brazil (MZUSP) and at the LAPEDONE collection as well (Table 1).

\section{Results}

During the sampling period, 11,149 alive mollusks were captured in the three reservoirs. These animals belong to three Gastropoda species: Melanoides tuberculata (Müller, 1774) (Thiaridae) $(\mathrm{n}=9,724 ; \mathrm{min}=$ $0 ;$ max $=795 ;$ mean $=30)$, Biomphalaria straminea $($ Dunker, 1848) (Planorbidae) $(\mathrm{n}=1,361 ; \min =0, \max =74 ;$ mean $=4.2)$ and Pomacea lineata (Spix, 1827) (Ampullariidae) $(\mathrm{n}=64 ; \min =0 ; \max =12 ;$ mean $=0.2$ ) (Figure 2).

When comparing species abundance among the reservoirs, Dona Maria Zeneide Viana de Andrade Reservoir had the highest number of mollusks $(n=5,417 ; 48.6 \%)$. Emparedade $(n=4,619 ; 41.4 \%)$ was the second most abundant followed by São Julião $(n=1,113 ; 10 \%)$. Despite the species abundance being different between the analyzed reservoirs, their composition remained the same among them. 

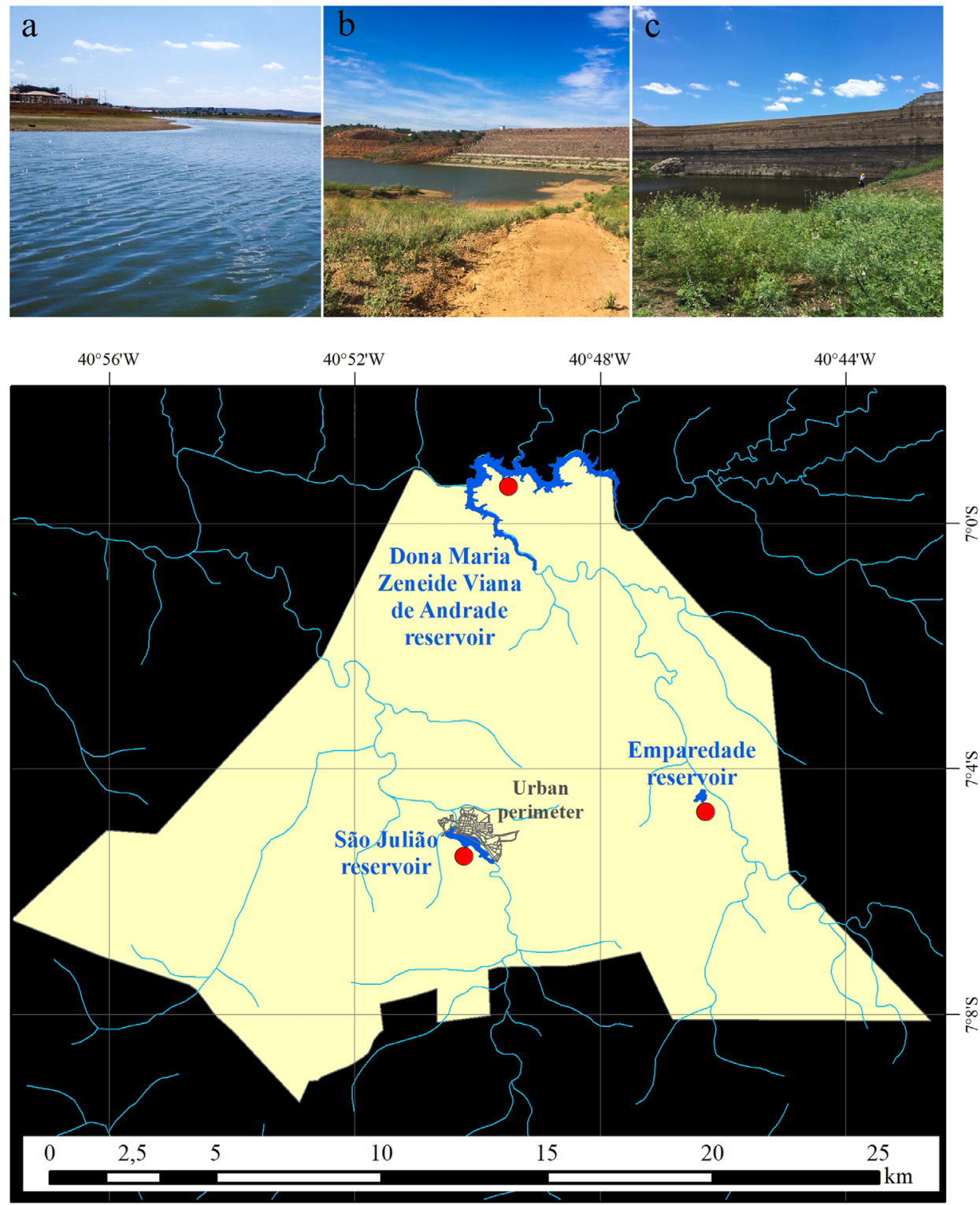

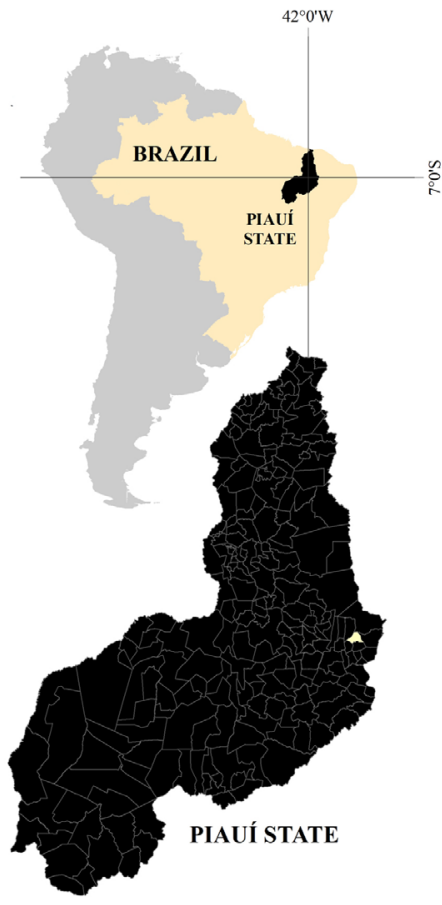

Universal Transverse Mercator coordinate system Datum SIRGAS $200023 \mathrm{k}$

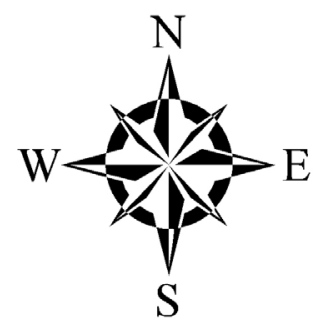

- Sampling locations Urban perimeter roads Drainage

Figure 1. Sampling locations in São Julião, Piauí, Brazil. Details of reservoirs surveyed a: São Julião; b: Dona Maria Zeneide Viana de Andrade and c: Emparedade (Adapted from Silva et al. 2019).

Table 1. Gastropoda species sampled in the reservoirs of São Julião, Piauí, Brazil, between June 2017 and April 2018.

\begin{tabular}{|c|c|c|c|}
\hline Order/Family & Species & $\begin{array}{l}\text { Voucher } \\
\text { number }\end{array}$ & Reservoir \\
\hline Basommatophora/Planorbidae & Biomphalaria straminea (Dunker, 1848) & CMIOC 11598 & \multirow{3}{*}{$\begin{array}{c}\text { São Julião } \\
\text { Reservoir } \\
7^{\circ} 05^{\prime} 02.6^{\prime \prime} \mathrm{S} 40^{\circ} 50^{\prime} 29.0^{\prime \prime} \mathrm{W}\end{array}$} \\
\hline Prosobranchia/Thiaridae & Melanoides tuberculata (Müller, 1774) & CMIOC 11599 & \\
\hline Prosobranchia/Ampullariidae & Pomacea lineata (Spix, 1827) & MZUSP 146748 & \\
\hline Basommatophora/Planorbidae & Biomphalaria straminea (Dunker, 1848) & CMIOC 11601 & \multirow{2}{*}{$\begin{array}{c}\text { Emparedade } \\
\text { Reservoir } \\
7^{\circ} 05^{\prime} 02.6^{\prime \prime} \mathrm{S} 40^{\circ} 50^{\prime} 29.0^{\prime \prime} \mathrm{W}\end{array}$} \\
\hline Prosobranchia/Thiaridae & Melanoides tuberculata (Müller, 1774) & CMIOC 11602 & \\
\hline Basommatophora/Planorbidae & Biomphalaria straminea (Dunker, 1848) & CMIOC 11604 & \multirow{3}{*}{$\begin{array}{c}\text { Dona Maria Zeneide Viana de Andrade } \\
\text { Reservoir } \\
7^{\circ} 05^{\prime} 02.6^{\prime \prime} \mathrm{S} 40^{\circ} 50^{\prime} 29.0^{\prime \prime} \mathrm{W}\end{array}$} \\
\hline Prosobranchia/Thiaridae & Melanoides tuberculata (Müller, 1774) & CMIOC 11605 & \\
\hline Prosobranchia/Ampullariidae & Pomacea lineata (Spix, 1827) & MZUSP 146751 & \\
\hline
\end{tabular}




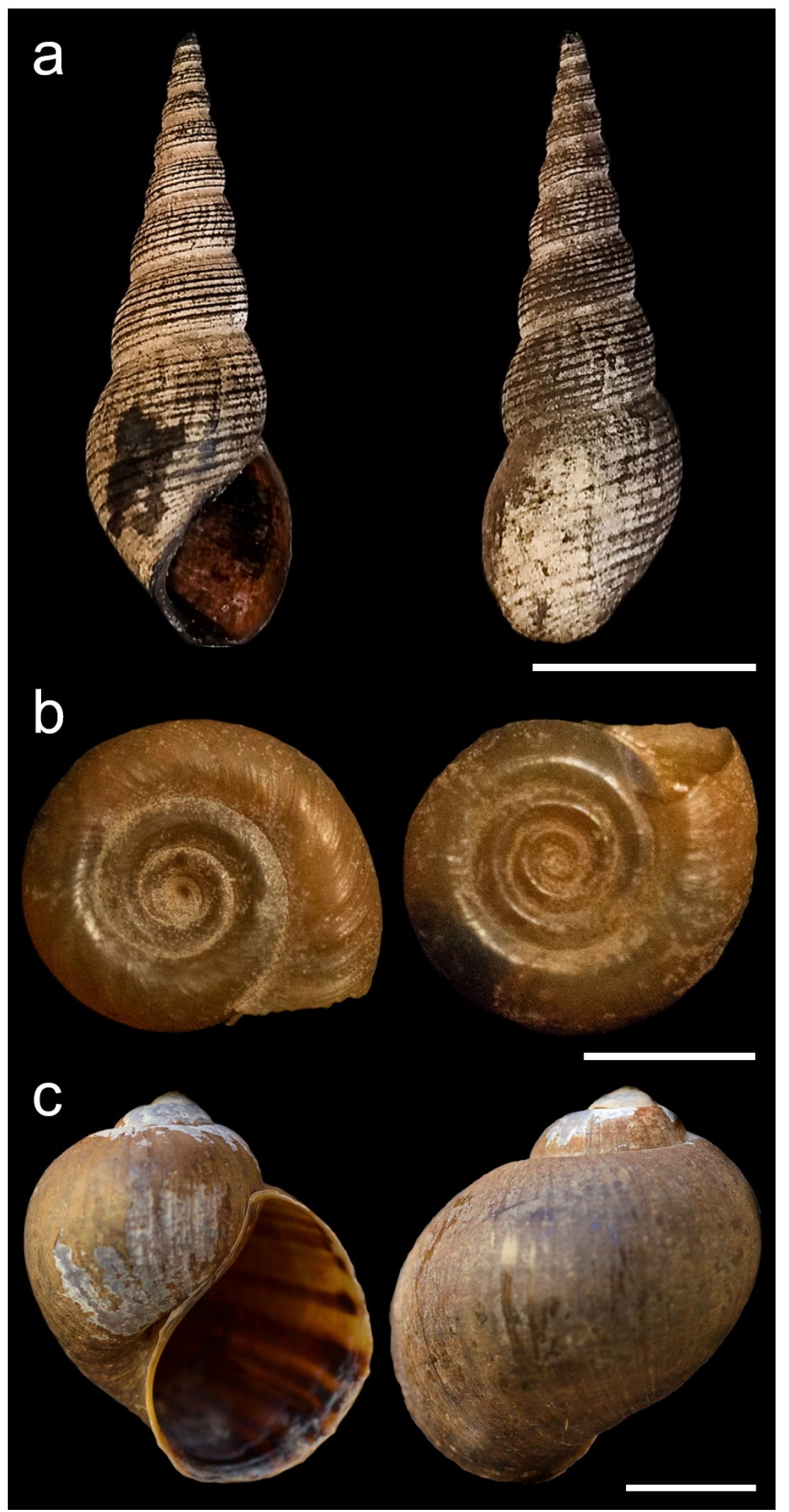

Figure 2. Mollusk species sampled in the reservoirs of São Julião, Piauí, Brazil. a: Melanoides tuberculata; b: Biomphalaria straminea and c: Pomacea lineata. Scale bars $=\mathrm{a}: 10 \mathrm{~mm}, \mathrm{~b}: 5 \mathrm{~mm}$ and c: $10 \mathrm{~mm}$. 
Melanoides tuberculata was the most abundant species among the three reservoirs, corresponding to 9,724 individuals $(87.2 \%$ of total sampled). This species had 4,894 specimens $(50.3 \%$; $\min =0$; $\max =401$; mean $=45.3$ ) in Dona Maria Zeneide Viana de Andrade Reservoir, while in Emparedade there were 3,762 individuals (38.7\%; $\min =0 ; \max =795 ;$ mean $=34.8)$, and 1,068 in São Julião Reservoir $(11 \% ; \min =0 ; \max =111 ;$ mean $=9.9)$. It was verified a significant difference in the abundance of individuals among the studied dams, of which only São Julião Reservoir differed in its results $(\mathrm{P} \leq 0.05$; d.f. $=$ 2; $\mathrm{X}^{2}=24.88$ ) (Figure 3a).

The second most abundant species in the study is B. straminea, corresponding to 1,361 individuals ( $12.2 \%$ of the entire sample). A total of 821 individuals were collected in Emparedade Reservoir (60.3\%; min $=0 ; \max =74$, mean $=7.7), 512$ individuals $(37.6 \% ; \min =0, \max =$ 64; mean $=4.8$ ) in Dona Maria Zeneide Viana de Andrade Reservoir and 28 individuals $(2.1 \%$; $\min =0 ; \max =4$, mean $=0.3)$ in São Julião reservoir, the least abundant of all. There was a significant difference in the abundance of mollusks of this species among the studied reservoirs, of which São Julião differed from the others surveyed $(\mathrm{P} \leq 0.05$; d.f. $=2$; $\mathrm{X}^{2}=78.79$ ) (Figure 3b).

Pomacea lineata was least abundant in all three reservoirs, comprising 64 individuals ( $0.6 \%$ of sampled animals). This species had 36 individuals in Emparedade reservoir (56.3\%; $\min =0, \max =12$, mean $=0.3)$, followed by 17 individuals in São Julião $(26.6 \%$; $\min =0$; $\max =5$; mean $=0.2$ ), and only 11 specimens in Dona Maria Zeneide Viana de Andrade Reservoir $(17.2 \% ; \min =0 ; \max =5 ;$ mean $=0.1)$. There was no significant difference in the abundance of individuals of this species among the reservoirs studied $\left(\mathrm{P}=0.06\right.$; d.f. $\left.=2 ; \mathrm{X}^{2}=5.54\right)$ (Figure 3c).

\section{Discussion}

Similar to other freshwater and marine invertebrates, freshwater gastropods present an overall pattern of high diversity in tropics, with decreasing species richness as well as decreasing endemicity at higher latitudes (Strog et al. 2008). According to the latter author, the rivers and streams of South America are surprisingly species-poor, however, it is not yet clear if this is a sampling/study artifact or an actual pattern. The fauna of mollusks sampled in the three reservoirs of São Julião is, in fact, not diverse, consisting of three species from only three families of Gastropoda. These results are similar to those described by studies carried out in the Brazilian Northeastern, a region which accumulates a history of low species diversity (Abílio et al. 2007, Oliveira \& Viana 2019).

Santos \& Eskinazi-Sant'Anna (2010) attempted to explain the relatively low variety observed in semiarid tropical regions, attributing to prolonged dry periods a condition that selects to snail's community. Considering this assertion, in case of intermittent rivers dammed, the time of water residence is a factor that can play an important role in this phenomenon because drives the stratification processes and nutrient availability, causing considerably changes in water properties (Straškraba 1999, Londe et al. 2016). Bennion et al. (2005) described that retention periods longer than 30 days are very sensitive to enrichment, making the water more susceptible to eutrophication. According to the latter authors, shallow and completely mixed aquatic environments present a very low potential for recovery. These attributes are similar to the ones verified in the reservoir complex studied in São Julião.

Although geographically close, the studied reservoirs are not connected. This autonomy implies that each environment will present a peculiar response to environmental variations. Emparedade and Dona Maria Zeneide Viana de Andrade reservoirs are located in a rural area, far from urban influence. It is possible to verify a large deforested area along the reservoirs margin, which allows the exposure of water column to light, causing a consequent increase in primary productivity. Conversely, São Julião reservoir is in urban perimeter, having significantly more vegetation at its margin, and it receives a considerable amount of non-treated sewage. Thus, these particularities of each of the studied reservoirs may have been responsible for the significant difference in mollusks abundance.

Previous studies conducted in different regions of the country considered the species found in the three reservoirs of São Julião tolerant and very adapted to environmental diversity. Biomphalaria straminea is widely distributed in Brazil, as a result of their ability to adapt to different climates and ecological conditions (Paraense, 1986). According to Kotzian \& Amaral (2013), B. straminea occurrence in water bodies of the semiarid region can be explained by their tolerance to dry periods, thus severe semi-arid conditions are not barriers to their survival. This species is the most important host of Schistosoma mansoni (Sambon, 1907) in Brazilian Northeastern. Pomacea lineata, in its turn, although less abundant, is quite resistant to desiccation. In a recent study, Glasheen et al. (2017) confirmed that the survival capacity of these animals to drought conditions, due to the behavior of fully burying itself in the substrate. Regarding M. tuberculata, this species has combined high tolerance to both salinities' levels (Farani et al., 2000, Silva \& Barros 2015, Bolaji et al., 2011) and temperature variations (Pointier 1993), and it also supports longer desiccation periods. Allied to this, it has a high reproductive capacity through parthenogenesis (Jacob 1957) and sexual reproduction (Samadi et al. 1999).

In São Julião reservoir complex, the abundance of $M$. tuberculata is seven times higher than all other native species registered. The high number of individuals observed is a consequence of the set of biological traits mentioned, which allows M. tuberculata to become a successful competitor in new environments, capable of even suppressing the growth of native species population. The role of this invasive species in the reduction of native species have been described in different environments (Freitas et al. 1987, Pointier 1999, Fernandez 2001, Almeida et al. 2018). There are reports of the decline in B. glabrata and $B$. straminea densities from the Southeastern region (Giovanelli et al. 2003, Almeida et al. 2018), as well as it was responsible for the low diversity and density indices of native species in Northeastern reservoirs (Almeida et al. 2018). Although the effect of $M$. tuberculata on mollusk community of the São Julião reservoirs has not been evaluated, the expressive differences observed among abundances of this species, B. straminea and Pomacea lineata, suggest attention to a putative interspecific competition.

The history of severe droughts in the region of São Julião promoted a larger interaction between human populations and their reservoirs. However, without proper sanitation conditions that this interaction requires, the risk of spreading water-borne diseases and environmental imbalance through the introduction of exotic species is imminent. The 

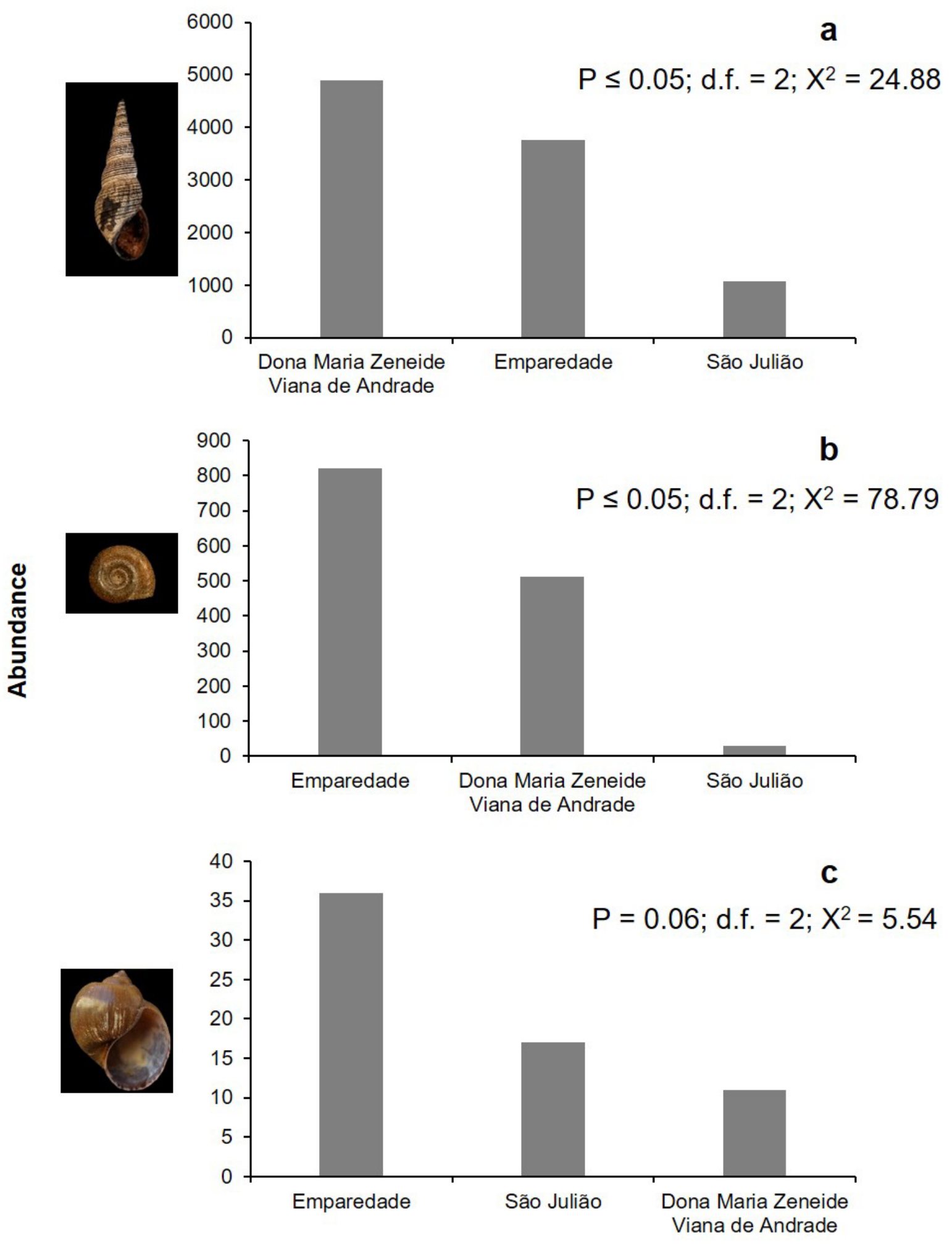

Reservoirs of São Julião

Figure 3. Abundance of Gastropoda species sampled in the three reservoirs of São Julião, Piauí, Brazil, between May 2017 and April 2018. Details of statistical tests in a: Melanoides tuberculata; b: Biomphalaria straminea and c: Pomacea lineata. Images of species out of scale. 
results obtained with this survey allowed us to make inferences about the influence of these water bodies on the malacofauna composition of the semiarid region as well as their interaction with the environment, besides recording the presence of $B$. straminea, which is the intermediate host of $S$. mansoni, in the studied region. This information is of paramount importance to local populations who depend on these water resources for a variety of activities.

\section{Acknowledgments}

The authors are grateful to the National Council for Scientific and Technological Development - CNPq (421582/2018-9) for providing financial support, to Instituto Federal do Piauí (PROAGRUPARINFRA 162/2017) for the logistic and financial support, to the Mollusk Collection of Instituto Oswaldo Cruz, Fundação Oswaldo Cruz, Rio de Janeiro, Brazil (CMIOC) and Museu de Zoologia da Universidade de São Paulo, São Paulo, Brazil (MZUSP) for the identification of specimens, and to the anonymous reviewers for their suggestions to our manuscript.

\section{Author contributions}

Edson Lourenço da Silva: Contribution to data analysis and interpretation.

Adriana Josefa da Rocha: Contribution to data collection.

Manuella Feitosa Leal: Contribution to data collection.

Orianna dos Santos: Contribution to data collection.

João Hemerson de Sousa: Contribution to data collection.

Antônia Rafaela Viana da Silva: Contribution to data collection.

Karina Ketelen Silva Dantas: Contribution to data collection.

Erika Maria Matos Rulim: Contribution to data collection.

Emerson Santos Castro: Contribution to data collection.

Ana Carolina Landim Pacheco: Contribution to critical revision, adding intellectual content.

Tamaris Gimenez Pinheiro: Contribution to critical revision, adding intellectual content.

\section{Conflicts of interest}

The authors declare that they have no conflict of interest related to the publication of this manuscript.

\section{References}

AB'SÁBER, A.N. 2003. Os domínios de natureza no Brasil: potencialidades paisagísticas. Ateliê Editorial, São Paulo, p. 159.

ABILIO, F.J.P., RUFFO, T.L.M., SOUZA, A.H.F.F., FLORENTINO, H.S., OLIVEIRA JUNIOR, E.T., MEIRELES, B.N. \& SANTANA, A.C.D. 2007. Macroinvertebrados bentônicos como bioindicadores de qualidade ambiental de corpos aquáticos da caatinga. Oecol Bras. 11(3):397-409.

AGOSTINHO, A.A., GOMES, L.C. \& PELICICE, F.M. 2007. Ecologia e manejo de recursos pesqueiros em reservatórios do Brasil. Editora da UEM, Maringá.

AGOSTINHO, A.A., THOMAZ, S.M. \& GOMES, L.C. 2005. Conservação da biodiversidade em águas continentais do Brasil. Megadiversidade. 1(1):70-78
ALMEIDA, P.R.S., FILHO, S.L.N. \& VIANA, G.F.S. 2018. Effects of invasive species snails in continental aquatic bodies of Pernambucano semiarid. Acta Limnol. Bras. 30: e103.

BAXTER, R.M. 1977. Environmental effects of dams and impoundments. Ann. Rev. Ecol. Evol. Syst. 8:255-283.

BENNION, H.T, HILTON, J., HUGHES, M., CLARK, J., HORNBY, D., FOZZARD, I., PHILLIPS, G. \& REYNOLDS, C. 2005. The use of a GISbased inventory to provide a national assessment of standing waters at risk from eutrophication in Great Britain. Sci. Total Environ. 344:259-273.

BOGAN, A. 2008. Global diversity of freshwater mussels (Mollusca, Bivalvia) in freshwater. Hydrobiologia. 595(1):139-147.

BOLAJI, D.A., EDOKPAYI, C.A., SAMUEL, O.B., AKINNIGBAGBE, R.O. \& AJULO, A.A. 2011. Morphological characteristics and salinity tolerance of Melanoides tuberculatus (Muller, 1774). World Journal of Biological Research. 4(2):1-11.

COLLEY, E., SIMONE, L.R.L. \& SILVA, J.L. 2012. Uma viagem pela história da Malacologia. Revista Estudos de Biologia: Ambiente e Diversidade. 34(83):175-190.

ESTEVES, F.A. 1998. Fundamentos de Limnologia. 2 ed. Interciência, Rio de Janeiro.

FACON, B., POINTIER, J.P., GLAUBRECHT, M., POUX, C., JARNE, P. \& DAVID, P. 2003. A molecular phylogeographic approach to biological invasions of the New World by parthenogenetic Thiarid snails. Mol. Ecol. 12:3027-3039.

FARANI, G.L., NOGUEIRA, M.M., JOHNSSON, R. \& NEVES, E. 2015. The salt tolerance of the freshwater snail Melanoides tuberculata (Mollusca, Gastropoda), a bioinvader gastropod. Pan-American Journal of Aquatic Sciences. 10(3):212-221.

FERNANDEZ, M.A., MATTOS, A.C., SILVA, E.F., SANTOS, S.B. \& THIENGO, S.C. 2014. A malacological survey in the Manso Power Plant, state of Mato Grosso, Brazil: new records of freshwater snails, including transmitters of schistosomiasis and exotic species. Rev. Soc. Bras. Med. Trop. 47(4):498-506.

FERNANDEZ, M.A., SILVA, A.F., ESTEVES, R.A., \& THIENGO, S.C. 2018. Snail transmitters of schistosomiasis and other mollusks of medical and economic importance at the Simplício Queda Única Hydroelectric Plant, Southeast Brazil. Rev. Soc. Bras. Med. Trop. 51(5):689-694.

FERNANDEZ, M.A., THIENGO, S.C. \& BOAVENTURA, M.F. 2001. Gastrópodes límnicos do Campus de Manguinhos, Fundação Oswaldo Cruz, Rio de Janeiro, RJ. Rev. Soc. Bras. Med. Trop. 34(3):279-282.

FREITAS, J.R., BEDÊ, L.C., DE MARCO, J.R., ROCHA, L.A. \& SANTOS, M.B.L. 1987. Population dynamics of aquatic snails in Pampulha Reservoir. Mem. Inst. Oswaldo Cruz. 87(Suppl. IV):299-305.

GIOVANELLI, A., VIEIRA, M.V. \& SILVA, C.L.P.A.C. 2003. Apparent competition through facilitation between Melanoides tuberculata and Biomphalaria glabrata and the control of schistosomiasis. Mem. Inst. Oswaldo Cruz. 98(3):429-431.

GLASHEEN, P.M., CALVO, C., MEERHOFF, M., HAYES, K.A. \& BURKS, R.L. 2017. Survival, recovery, and reproduction of apple snails (Pomacea spp.) following exposure to drought conditions. Freshwater Science. 36(2):000-000.

HERSHLER, R., PEREZ, K.E., ROTH, B., SEDDON, M., STRONG, E.E. \& THOMPSON, F.G. 2004. The Global Decline of Nonmarine Mollusks. BioScience. 54(4):321-330.

IBGE. https://cidades.ibge.gov.br/brasil/pi/sao-juliao/panorama (last access in 07/may/2019).

JACOB, J. 1958. Cytological studies of Melaniidae (Mollusca) with special reference to parthenogenesis and polyploidy. II. A study of meiosis in the rare males of the polyploid race of $M$. tuberculata and M. lineatus. Trans. R. Soc. Edinb. 63(16):433-444. 
KOTZIAN, C.B. \& AMARAL, A.M.B. 2013. Diversity and distribution of mollusks along the Contas River in a tropical semiarid region (Caatinga), Northeastern Brazil. Biota Neotrop. 13(4):299-314. http://www. biotaneotropica.org.br/v13n4/pt/fullpaper?bn03313042013+en (último acesso em 22/maio/2019)

LONDE, L.R., NOVO, E.M.L.M., BARBOSA, C. \& ARAUJO, C. A. S. 2016. Water residence time affecting phytoplankton blooms: study case in Ibitinga Reservoir (São Paulo, Brazil) using Landsat/TM images. Braz. J. Biol. 76(3):664-672

LYDEARD, C., COWIE, R.H., PONDER, W.F., BOGAN, A.E., BOUCHET, P., CLARK, S.A., CUMMINGS, K.S., FREST, T.J., GARGOMINY, O., HERBERT, D.G. \& MALVEZZI, R. 2007. Semiárido: uma visão holística. Pensar Brasil, Brasília.

MEDEIROS, C., AZEVÊDO, E., BARBOSA, J. \& MOLOZZI, J. 2018. Effectiveness of abundance and biomass curves in detecting environmental alterations in semi-arid region reservoirs. Biota Neotrop. 18(2):1-9. http://www.biotaneotropica.org.br/v18n2/en/fullpaper?bn00218022018+en (last access in 22/may/2019)

OLIVEIRA, C.D.K. \& VIANA, G.F.S. 2019. Influência dos parâmetros abióticos na abundância de Biomphalaria straminea (Basommatophora: Planorbidae) em uma lagoa temporária no semiárido de Pernambuco, Brasil. Oecol. Aust. 23(1):90-98.

PARAENSE, W.L. 1986. Distribuição dos caramujos no Brasil. In Anais da Academia Mineira de Medicina. Modernos conhecimentos sobre esquistossomose mansônica (F.A. Reis, J. Faria \& N. Katz, eds). Academia Mineira de Medicina, Belo Horizonte, p. 117-128.

PINTO, H.A. \& MELO, A.L. 2011. A checklist of trematodes (Platyhelminthes) transmitted by Melanoides tuberculata (Mollusca: Thiaridae). Zootaxa. 2799:15-28

POINTIER, J.P. 1993. The introduction of Melanoides tuberculata (Mollusca: Thiaridae) to the island of Saint Lucia (West Indies) and its role in the decline of Biomphalaria glabrata, the snail intermediate host of Schistosoma mansoni. Acta Tropica. 54:13-18.

POINTIER, J.P. 1999. Invading freshwater Gastropods: Some conflicting aspects for public health. Malacologia. 41(2):403-411.

POMBO, V.B. Moluscos límnicos. 2016. In Espécies exóticas invasoras de águas continentais no Brasil (A.O. Latini, D.C. Resende, V.B. Pombo \& L. Coradin, eds). Ministério do Meio Ambiente, Brasília, p. 123-231.

ROCHA, O., ESPÍNDOLA, E.L.G., RIETZLER, A.C., FENERICH-VERANI, N. \& VERANI, J.R. 2011. Animal invaders in São Paulo state reservoirs. Oecol. Aust. 15(3):631-642.
SAMADI, S., MAVAREZ, J., POINTIER, J.P., DELAY, B. \& JARNE, P. 1999. Microsatellite and morphological analysis of population structure in the parthenogenetic freshwater snail Melanoides tuberculata: insights into the creation of variability. Mol. ecol. 8(7):1141-1153.

SANTOS, C.M. \& ESKINAZI-SANT'ANNA, E.M. 2010. The introduced snail Melanoides tuberculata (Muller, 1774) (Mollusca: Thiaridae) in aquatic ecosystems of the Brazilian Semiarid Northeast (Piranhas-Assú River basin, State of Rio Grande do Norte). Braz. J. Biol. 70(1):1-7.

SANTOS, S.B., THIENGO, S.C., FERNANDEZ, M.A., MIYAHIRA, I.C., GONÇALVES, I.C.B., XIMENES, R.F., MANSUR, M.C.D. \& PEREIRA, D. 2012. Espécies de moluscos límnicos invasores no Brasil. In Moluscos límnicos invasores no Brasil: Biologia, prevenção e controle (M.C.D. Mansur, C.P. Santos, D. Pereira, I.C.P. Paz, M.L.L. Zurita, M.T.R. Rodriguez, M.V. Nehrke \& P.E.A. Bergonci, eds). Redes Editora, Porto Alegre, p. 25-50.

SEPLAN. http://www.seplan.pi.gov.br/. (last access in 22/may/2019)

SILVA, E.C. \& BARROS, F. 2015. Sensibility of the invasive snail Melanoides tuberculata (Müller, 1774) to Salinity Variations. Malacologia. 58(12):365369.

SILVA, E.L., LEAL, M.F., SANTOS, O., ROCHA, A.J., PACHECO, A.C.L \& PINHEIRO, T.G. 2019. New records of the invasive mollusk Melanoides tuberculata (Müller, 1774) (Gastropoda, Thiaridae) in the Brazilian Northeast. Check List 15 (3): 479-483.

STRAŠKRABA, M. 1999. Retention time as a key variable of reservoir limnology. In Theoretical reservoir ecology and its application (J.G. Tundisi \& M. Straškraba, eds). Backhuys Publishers, São Carlos, p. 385-410.

STRONG, E.E., GARGOMINY, O., PONDER, W.F. \& BOUCHET, P. 2008 Global diversity of gastropods (Gastropoda; Mollusca) in freshwater. Hydrobiologia. 595:149-166.

SUDENE. http://www.sudene.gov.br/. (last access in 22/may/2019)

THIENGO, S.C., FERNANDEZ, M.A. \& SANTOS, S.B. 2005. Malacofauna límnica da área de influência do lago da usina hridrelétrica de Serra da Mesa, Goiás, Brasil. I. Estudo qualitativo. Rev. Bras. Zool. 22(4):867-874.

TUNDISI, J.G. 2003. O Futuro dos Recursos - Recursos Hídricos. MultiCiência. 11:1-10.

TUNDISI, J.G. 2008. Recursos hídricos no futuro: problemas e soluções. Estudos Avançados. 22 (63):7-16.

TUNDISI, J.G., TUNDISI, T.M. \& ROCHA, O. 2002. Ecossistemas de águas interiores. In Água doce no Brasil. Capital ecológico, uso e conservação (A.C. Rebouças \& B. Barbosa, eds). Escrituras, São Paulo, p.153-179.

VOGLER, R.E., NÚNEZ, V., GREGORIC, D.E.G., BELTAMINO, A.A. \& PESO, J.G. 2012. Melanoides tuberculata: The history of an invader. In Snails: Biology, ecology and conservation (E.M. Hämäläinen \& S. Järvinen, eds) Nova Science Publishers, New York, p. 65-84. 